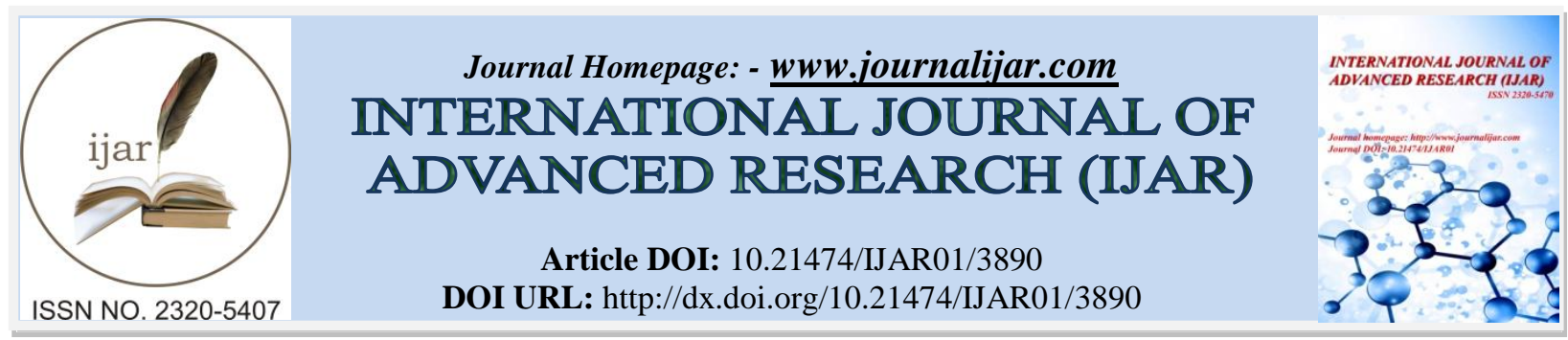

RESEARCH ARTICLE

\title{
IMPLEMENTATION STRATEGY OF TIMBER LEGALITY VERIFICATION SYSTEM (SVLK) IN THE FURNITURE INDUSTRY IN INDONESIA: SWOT AND AHP ANALYSIS.
}

Mukti Ali Pane* and Zhang Jing.

College of Environmental Science and Engineering, Tongji University, Institute of Environment for Sustainable Development (IESD), 20092, Shanghai, P.R. China.

\section{Manuscript Info}

Manuscript History

Received: 08 February 2017

Final Accepted: 05 March 2017

Published: April 2017

Key words:-

SVLK; Furniture industry; Indonesia; SWOT; AHP

\begin{abstract}
The objective of this study was to identify best implementation strategy of Timber Legality Verification System (SVLK) in the furniture industry in Indonesia using Strength, Weakness, Opportunity, and Threat (SWOT) and Analytical Hierarchy Process (AHP) approaches. SWOT analysis distinguishes internal and external factors based on experts consultation. A hierarchy analytical structure was then developed with goal, criteria/factors, and the alternatives strategies identified in the SWOT matrix. The various criteria/factors, and alternatives were graded by experts and then computed using Expert Choice software. Best alternative was identified according to the results. The best alternative implementation strategy of SVLK in the furniture industry in Indonesia was found to be incentives to furniture industry. This indicates that the furniture industry in Indonesia is in need of full government support to encourage the entire furniture industry to get SVLK certificate. The incentive is recognized as a form of stimulant to industry and the implementation of these incentives can take the form of cost subsidy, technical assistance on easiness in licensing, export process, and others. This would ensure immediate gain of the SVLK certification, impacts, and best performance for the successful implementation of SVLK in the furniture industry in Indonesia.
\end{abstract}

Copy Right, IJAR, 2017,. All rights reserved.

\section{Introduction:-}

Indonesia furniture industry processes raw materials or semi-finished materials of wood, rattan, and other natural raw materials into finished goods. Furniture products get high value and hence advantageous when accepted by retailers and exporters (Melati, et al., 2013). The furniture industry provides a lot of job opportunities. According to the Indonesia Furniture and Handicraft Industry Association, locally known as Asosiasi Industri Permebelan dan Kerajinan Indonesia (ASMINDO), furniture industry provides about 4 million direct and indirect labors. Furniture industry has significant contribution to the national economy, where export volume of furniture from Indonesia increased by $2.4 \%$ from 2011 to 2015, with a value of US $\$ 1.42$ billion in 2015. Most products exported during this period were items of wooden furniture (94.5\%) and rattan (5.5\%) (BPS, 2017). Over this period, Indonesia's main export destinations for furniture products were the United States ranking first followed by Japan, the United Kingdom, France, Netherlands, Australia, Germany, South Korea, Belgium, and Taiwan (BPS, 2016).

Corresponding Author:- Mukti Ali Pane.

Address:- College of Environmental Science and Engineering, Tongji University, Institute of Environment for Sustainable Development (IESD), 20092, Shanghai, P.R. China. 
A decrease in the quality and quantity of forest in Indonesia has occurred since the 1990s. Deforestation and degradation of forest resources occurred because forest management which accounts for was not sustainability oriented. Indonesia had a forest area of 96.49 million hectares (ha), 51.53\% of the land area, in 2015. In 2013-2014, forest area decreased to 170.63 million ha due to deforestation in this period (MoEF, 2016). The annual average net deforestation rate was 0.7 percent during the period 2010-2015 (FAO, 2015). The estimated cost of illegal logging is between US $\$ 30$ billion and US $\$ 100$ billion or $10 \%$ to $30 \%$ of the timber exchange worldwide every year (Nellemann, et al., 2012). In Indonesia according to the Ministry of Environment and Forestry (MoEF), the cause of degradation and deforestation is very complex, with the main reasons being illegal logging (MoEF, 2017). The ministry also found out that more than 10 million $\mathrm{m}^{3}$ of logs and sawn timber is smuggled every year resulting to economic loss worth approximately 30-40 trillion Indonesia Rupiah (IDR) or about US\$ 4 billion per year. Similarly, Nurrochmat et al. (2016) estimates that timber losses due to illegal logging and stealing amounts to around 25 trillion IDR or US\$2.1 billion every year. This shows that the estimations almost concur.

In the last few years, the issue of rampant illegal logging and illegal timber trading elicited reactions of international environmental organizations against tropical wood products including furniture. These environmental organizations campaigned to the end users in the main furniture export destinations persuading them to buy only those products that have Ecolabel certification (Cashore, et al., 2014). In Indonesia, efforts addressing illegal logging have been done by the Government of Indonesia, through MoEF with Indonesia signing Memorandum of Understanding (MoU) cooperation with other countries such as the United Kingdom in 2002, Norway in 2002, China in 2002, Japan in 2003 and United States in 2006, in order to combat illegal logging and illegal businesses (Setiono, et al., 2005).

In addition, Indonesia has cooperated with the European Union (EU) in handling the problem of illegal logging through Forest Law Enforcement, Governance, and Trade-Voluntary Partnership Agreement (FLEGT-VPA) since May 2003. However, various initiatives effectively prevented illegal logging and illegal timber trading (Setianingsih, 2009). Based on FLEGT-VPA, partner countries are required to develop control systems to verify the legality of timber exported to the European Union. The EU in return provides support related to the construction or completion of this control system; if they could agree and implement, this cooperation would bind both parties to the trade only on legal wood products that have been verified (Heeswijk, et al., 2013).

Indonesia as a partner country of FLEGT-VPA has developed the SVLK, aiming to build a credible, efficient, and fair tool addressing the problem of illegal logging. SVLK includes in context forest and forest product certification (Maryudi, 2016). To ensure that Indonesia's wood products are free from illegal logging practices, the government of Indonesia implements this framework of SVLK.

In Indonesia, Timber Legality Verification System (SVLK) is one type of ecolabel for controlling a movement of the timber furniture industry. SVLK is a tracking system developed by multistakeholder to ensure the legality of timber sources circulated and traded in Indonesia. SVLK was developed to encourage the implementation of government regulations that applies to the trade and distribution of legal forest products in Indonesia. With SVLK, consumers outside the country do not need to doubt the legality of timber from Indonesia. The legality of timber that make the farmers and entrepreneurs furniture can convince buyers from abroad, therefore the sale of the products will be increased (LEI, 2017).

The purpose of this paper therefore is to find out the factors that influence the implementation of SVLK in the furniture industry in Indonesia, and to find out the best alternative implementation strategy of SVLK in the furniture industry in Indonesia using SWOT and AHP methods.

\section{Overview of SVLK in Indonesia:-}

Timber Legality Verification System locally known as Sistem Verifikasi Legalitas Kayu (SVLK) is a regulatory instrument on trade in timber products enforced by MoEF (Cashore \& Stone, 2012). The development of the system began in 2002 when forestry stakeholders started drafting a legal standard for the timber trade. The SVLK came into force in June 2009 when the Government of Indonesia issued the regulation through the Minister of Forestry No P38/Menhut-II/2009. This has been revised to include, among others, P43/Menhut-II/2014 concerning Performance Assessment of Sustainable Production Forest Management and Timber Legality Verification to Permit Holders or Private Forests, more easily called SVLK (MoEF, 2017). The domestic and international organizations now view it as one of the most promising mechanisms for addressing illegal logging in Indonesia (Pohnan, et al., 2013). 
The scope of the standard covers a wide range of issues such as harvesting rights and cutting permits, labor rights, environmental protection, and social impacts. However, there are concerns about its robustness particularly with regard to the issue of artisanal forest practices, local communities, and their rights (Nurrochmat et al., 2014; Obidzinski and Kusters, 2015).

\section{Methodology:-}

The study employed Strength, Weakness, Opportunity and Threats (SWOT) analysis approach and Analytical Hierarchy Process (AHP) method. SWOT analysis is used to identify factors systematically in order to formulate a strategy based on the logic that maximizes the strengths and opportunities and simultaneously minimizes the weaknesses and threats. Therefore, SWOT analysis as a tool used to develop strategy is based on the external environment (opportunities and threats) and internal environment (strengths and weaknesses) (David, 2011). While Analytical Hierarchy Process (AHP) is an analytical tool that systematically approaches the problem holistically in stages. It combines qualitative information and numerical process matrix manipulation based on ordinal scale. AHP can also be used to select some alternative strategies available in the formulation of the strategy (Marimin, et al., 2010). The use of AHP in comparing two elements can be achieved in various ways but the most commonly used in comparing alternatives is the one that gives values in a scale of 1-9 giving the importance of an alternative in comparison to another ( Donegan, et al., 1991) as shown in table 1. According to Kurttila et al. (2000) the combined SWOT with AHP methodology applied is in order to reach the aims of study in determining the best alternative.

Table 1:- Pairwise Comparison Scale.

\begin{tabular}{|c|c|}
\hline Intensity of importance & Definition \\
\hline 1 & A and B of equal importance \\
\hline 3 & A more important than B \\
\hline $1 / 3$ & B slightly more important than A \\
\hline 5 & A more important than B \\
\hline $1 / 5$ & B obviously more important than A \\
\hline 7 & A lot more important than B \\
\hline $1 / 7$ & B very obviously more important than A \\
\hline 9 & A overwhelmingly more important than B \\
\hline $1 / 9$ & B absolutely more important than A \\
\hline $2,4,6,8$ or $1 / 2,1 / 4,1 / 6,1 / 8$ & Intermediate values between two adjacent judgments \\
\hline
\end{tabular}

\section{Study Area:-}

The study was conducted in Indonesia and it focused in the capital city Jakarta and Bogor. Selection of place in this region was because the respondent and many forestry stakeholders as perpetrators and monitoring of policies as well as export-oriented furniture industry in Indonesia are based in the two cities.

\section{Data Collection:-}

In this study, the primary data were collected from August to October 2016. Primary data was collected through interviews and questionnaires to 17 key informants. The distribution of the respondents was as follows: 5 from MoEF, 6 from the Ministry of Trade (MoT), 2 from the National Accreditation Body (KAN), 1 from PT. BRIK Quality Services (BRIK), 1 from Independent Forestry Monitoring Network (JPIK), 1 from the Indonesian Center for Environmental Law (ICEL), and 1 from Indonesia Furniture and Handicraft Industry Association (ASMINDO). The respondents were experts and practitioners who have knowledge, skills, and experience related to SVLK. Secondary information in this study consists of the study of literature, journals, internet, official reports, and other relevant information sources used to cross check and inform the primary data.

\section{Data Analysis:-}

The first stage of the SVLK implementation strategy study involved identification and preparation of a list of strengths, weaknesses, opportunities, and threats made from interviews and questionnaires. SWOT diagram of factors influencing implementation of SVLK was then constructed where the strength and weakness were called internal factors, and opportunity and threat, external factors. Thereafter, SWOT matrix was developed by matching the internal environmental factors with external environmental factors that produced alternative strategies. These alternative implementation strategies were then tested by AHP. The Expert Choice 11 Software was thereafter used to compute the overall priority of criteria and alternatives from where the best alternative was chosen. 


\section{Results and Discussion:-}

Internal and External Environment Analysis:-

The internal environment analysis aimed to identify and explain the factors that become strengths and weaknesses of the implementation of SVLK in the furniture industry in Indonesia. External environment analysis aimed to identify and explain the factors that become opportunities and threats to the implementation of SVLK. The results from interview, questionnaire, and literature review are presented in table 2.

Table 2:- SWOT Matrix of the implementation of SVLK.

\begin{tabular}{|c|c|c|}
\hline & \multicolumn{2}{|c|}{ Internal Factor } \\
\hline & Strength (S) & Weakness (W) \\
\hline & $\begin{array}{l}\text { 1. Indonesia government policies } \\
\text { that have ratified the Voluntary } \\
\text { Partnership Agreement (VPA) with } \\
\text { the European Union } \\
\text { 2. The involvement of stakeholders } \\
\text { in policy making of SVLK } \\
\text { 3. The centres of the furniture } \\
\text { industry in Indonesia with a market } \\
\text { share of exports }\end{array}$ & $\begin{array}{l}\text { 1. Unpreparedness of companies } \\
\text { mainly classified as Small and } \\
\text { Medium Enterprises (SMEs) } \\
\text { 2. Raises of new fees } \\
\text { 3. The difference in perception } \\
\text { towards SVLK between the } \\
\text { Government and the business world } \\
\text { 4. Number of Timber Verification } \\
\text { Legality Agencies (LVLK) with } \\
\text { company furniture is not comparable } \\
\text { and the limited number of Timber } \\
\text { Legality Verification auditors } \\
\text { 5. The local market for SVLK } \\
\text { certified products is not established } \\
\text { yet }\end{array}$ \\
\hline \multicolumn{3}{|l|}{ External Factor } \\
\hline $\begin{array}{l}\text { Opportunity (O) } \\
\text { 1. The government policies in } \\
\text { major export destination countries } \\
\text { require the legal timber for } \\
\text { Indonesian timber based furniture } \\
\text { industries. } \\
\text { 2. Pressure from international } \\
\text { environmental organizations to use } \\
\text { legal timber products } \\
\text { 3. The perception of foreign buyers } \\
\text { who provide a good image towards } \\
\text { the companies that care about } \\
\text { conservation of the environment } \\
\text { 4. The existence of furniture } \\
\text { market network of certified timber } \\
\text { raw material that are environment- } \\
\text { friendly }\end{array}$ & $\begin{array}{l}\text { SO strategies } \\
\text { 1. Providing incentives to the } \\
\text { furniture industry to encourage } \\
\text { whole furniture industry to } \\
\text { immediately gain the certificate } \\
\text { SVLK (S1, S3, O1). }\end{array}$ & $\begin{array}{l}\text { WO strategies } \\
\text { 1. Assistance strategy for Small and } \\
\text { Medium Enterprises (SMEs) through } \\
\text { the socialization to all furniture } \\
\text { industries as well as improving } \\
\text { education and training of SVLK } \\
\text { auditors (W1, W3, W4, O1). } \\
\text { 2. Group Certification (W1, W2, } \\
\text { O1). }\end{array}$ \\
\hline $\begin{array}{l}\text { Threat (T) } \\
\text { 1. There is still no proven } \\
\text { international market acceptance } \\
\text { against SVLK } \\
\text { 2. The existence of illegal timber } \\
\text { trade } \\
\text { 3. Cheap furniture products from } \\
\text { other countries }\end{array}$ & $\begin{array}{l}\text { ST strategies } \\
\text { 1. Promotion of SVLK and } \\
\text { campaign against illegal timber } \\
\text { trading }(\mathrm{T} 1, \mathrm{~T} 2, \mathrm{~S} 2) \text {. }\end{array}$ & $\begin{array}{l}\text { WT Strategies } \\
\text { 1. Voluntary in furniture industry } \\
(\mathrm{T} 1, \mathrm{~W} 1, \mathrm{~W} 4, \mathrm{~W} 5) \text {. }\end{array}$ \\
\hline
\end{tabular}

Source: based on information from respondents

Note: $\mathrm{S}=$ Strength, $\mathrm{W}=$ Weakness, $\mathrm{O}=$ Opportunity, $\mathrm{T}=$ Threat 


\section{Hierarchical Structure Development:-}

In formulating the implementation strategy of SVLK in the furniture industry in Indonesia, we used AHP. After criteria/factors and alternatives were identified from the interviews and questionnaires, finalized hierarchical structure was developed (Figure 1). The developed hierarchical structure of the problem in which the first level has the goal. The second level consists of four criteria/factors, which are (1) Government policy, (2) Readiness of implementing bodies, (3) Readiness of businessmen, and (4) Market acceptance. The last level is the five strategy alternatives. The study found out the following alternative strategies: (1) Assistance, socialization, education and training, (2) Incentives to furniture industry, (3) Group certification, (4) Promotion of SVLK and campaign against illegal timber trading, and (5) Voluntary in furniture industry.

In an effort to understand the priority implementation strategy of SVLK in the furniture industry in Indonesia, the perception of experts and practitioners was tested by the AHP to know (1) The strategic factors that affect the success of the implementation of SVLK, and (2) The best strategy (alternative strategy) for achieving success in implementation of the SVLK. 
Goal

Implementation Strategy of SVLK in the Furniture Industry in Indonesia

Source: Prepared by the authors
Criteria

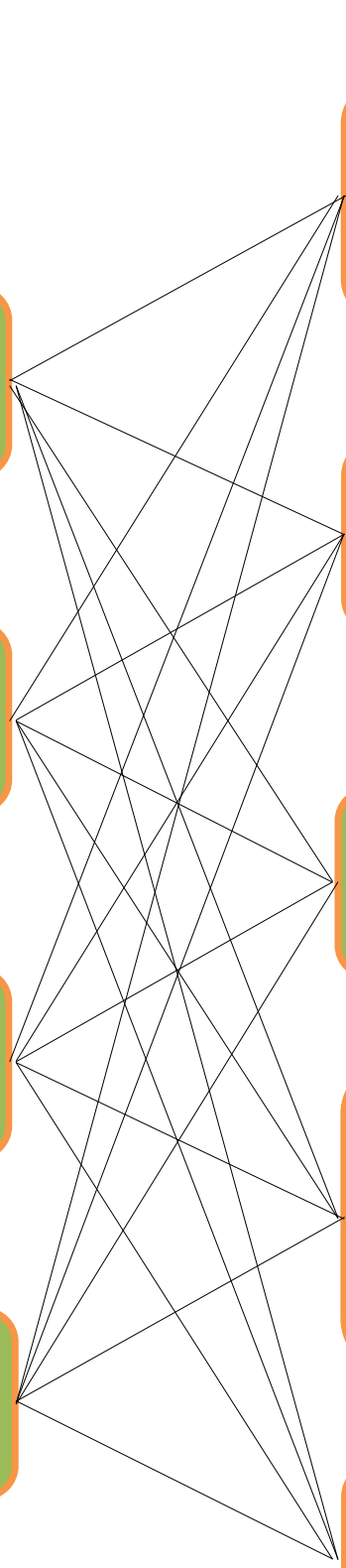

Readiness of businessmen

Market

Acceptance

Readiness of implementing bodies

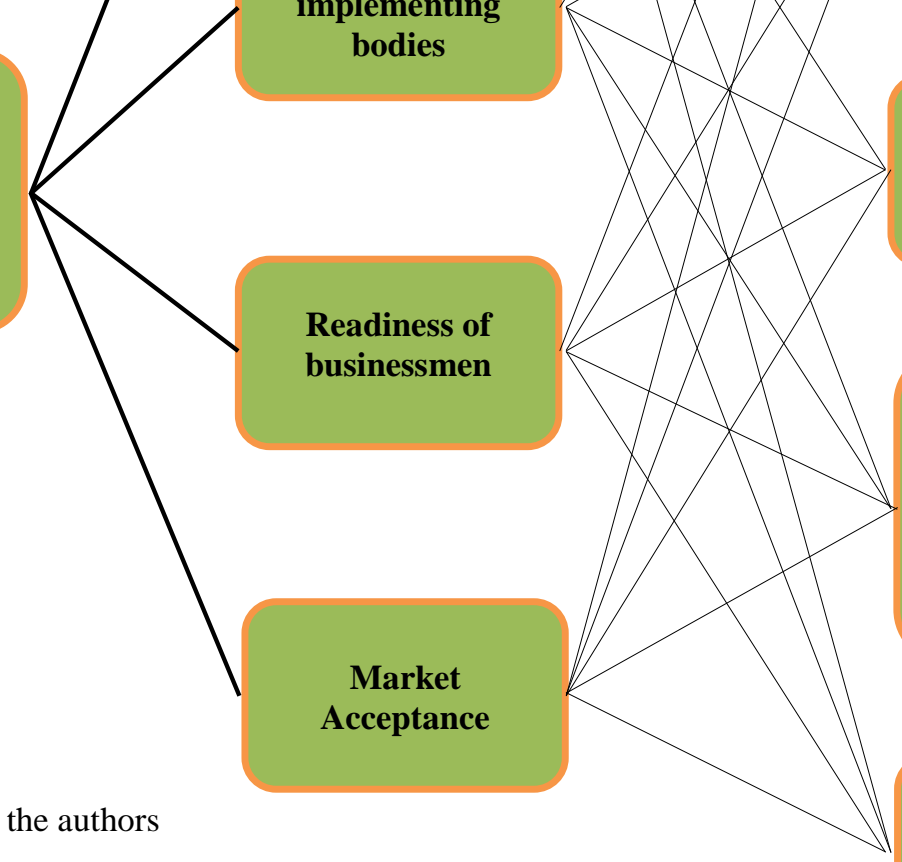

Figure 1:- AHP-based Hierarchy Structure.
Alternative

Assistance,

Socialization,

Education and

Training

\section{Group certification}

Promotion of

SVLK and

campaign against

illegal timber trading

Voluntary in

furniture industry 
Analysis of Alternative Implementation Strategies (using Expert Choice 11 Software)

Priority of Criteria:-

\begin{tabular}{|l|l|r|r|r|}
\hline & Government policy & Readiness of implementing bodies & Readiness of businessmen & Market acceptance \\
\hline Government policy & & 1.40268 & 2.88635 & 2.06707 \\
\hline Readiness of implementing bodies & & & 1.06676 & 1.44477 \\
\hline Readiness of businessmen & & & 1.56493 \\
\hline Market acceptance & Incon: 0.03 & & \\
\hline \hline
\end{tabular}

Figure 2:- Pair wise matrix of criteria.

Priorities with respect to:

Combined Goak: Implementation Strategy of 5 VLK in the Furiture Industry in Indonesia

Government policy

Readiness of implementing bodies

Readiness of businessmen

Market acceptance

Inconsistency $=0.03$

with 0 missing judgments.

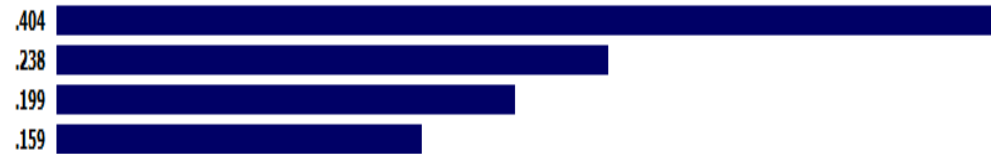

Figure 3:- Computed criteria priorities.

From the analysis results presented in figure 3, it is shown that a major deciding factor in the implementation of SVLK in the furniture industry in Indonesia is through government policy with the highest weight of 0.404 . This is understandable given that SVLK is essentially a product of government issued policies, although in concept development and aim to involve many stakeholders. However, everything is fixed to the government as a regulator; the government as regulator plays a very vital role in the implementation of SVLK in the field.

The implementation of SVLK involves not only the central government but also to local governments. The central government is directly involved namely, the MoEF as a regulator, MoT with the Forestry Industry Products Exporters (ETPIK) which is a permit issued by the Directorate General of Foreign Trade, Ministry of Industry as the government institution that houses the domestic industry as well as the Ministry of Finance through the Directorate General of Customs Duties as executor of SVLK in the field. While the involvement of local governments are related to business licensing and timber trade documents issued in their respective areas. Moreover, SVLK is also associated with foreign governments that involve the Ministry of Foreign Affairs. With so many government institutions involved, it takes good communication and coordination and intensive inter-ministerial interaction to enhance order and avoid SVLK policy from becoming counterproductive for the business world.

Priority of alternative:-

\section{Government Policy:-}

\begin{tabular}{|l|rrrr|r|}
\hline & Incentives to furniture Assistance, socialization \& education & Group Certification & Promotion of SVLK and campaign against illegal Voluntary in furniture industry \\
\hline Incentives to furniture industry & 1.27598 & 2.59758 & 2.49676 & 3.04615 \\
\hline Assistance, socialization \& education & & 1.72813 & 2.00588 & 2.54667 \\
\hline Group Certification & & & 1.0993 & 3.04615 \\
\hline Promotion of SVLK and campaign ac & & & & 1.56493 \\
\hline Voluntary in furniture industry & Incon: 0.02 & & & \\
\hline
\end{tabular}

Figure 4:- Pair wise matrix alternative to government policy criterion. 


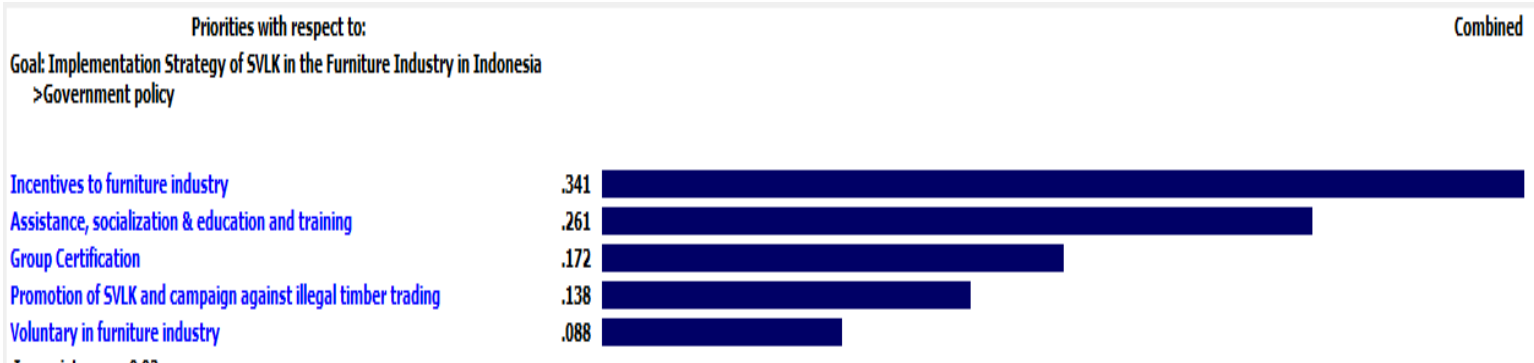

Inconsistency $=0.02$

with 0 missing judgments.

Figure 5:- Computed alternative priorities with respect to government policy criterion.

\section{Readiness of implementing bodies:-}

\begin{tabular}{|c|c|c|c|c|c|}
\hline & \multicolumn{5}{|c|}{ Incentives to furniture Assistance, socialization \& education Group Certification Promotion of SVLK and campaign against illegal Voluntary in furniture industry } \\
\hline Incentives to furniture industry & & 1.04585 & 1.76268 & 1.39567 & 3.17143 \\
\hline Assistance, socialization \& educa & & & 2.13979 & 2.92933 & 3.36544 \\
\hline Group Certification & & & & 1.51175 & 1.85365 \\
\hline Promotion of SVLK and campaig & & & & & 1.67698 \\
\hline Voluntary in furniture industry & Incon: 0.01 & & & & \\
\hline
\end{tabular}

Figure 6:- Pair wise matrix to Readiness of implementing bodies criterion.

Priorities with respect to:

Combined

Goal: Implementation Strategy of SVLK in the Furniture Industry in Indonesia

$>$ Readiness of implementing bodies

Incentives to furniture industry

Assistance, socialization \& education and training

Group Certification

Promotion of 5VLK and campaign againstillegal timber trading

Voluntary in furniture industry

Inconsistency $=0.01$

with 0 missing judgments.

Figure 7:- Computed alternative priorities with respect to Readiness of implementing bodies' criterion.

\section{Readiness of businessmen}

\begin{tabular}{|c|c|c|c|c|c|}
\hline & \multicolumn{5}{|c|}{ Incentives to furniture Assistance, socialization \& education Group Certification Promotion of SVLK and campaign against illegal Voluntary in furniture industry } \\
\hline Incentives to furniture industry & & 1.04585 & 2,06707 & 1.99586 & 1.85187 \\
\hline Assistance, socialization \& educcation & & & 1.0993 & 2.13013 & 2.47129 \\
\hline Group Certification & & & & 1.25097 & 1.36116 \\
\hline Promotion of SVLK and campaign ac & & & & & 1.31427 \\
\hline Voluntary in furniture industry & Incon: :0.1 & & & & \\
\hline
\end{tabular}

Figure 8:- Pair wise matrix to Readiness of businessmen criterion. 
Priorities with respect to:

Combined

Goal: Implementation Strategy of SVLK in the Funiture Industry in Indonesia $>$ Readiness of businessmen

Incentives to furniture industry

Assistance, socialization \& education and training

Group Certification

Promotion of 5VLK and campaign againstillegal timber trading

Voluntary in furniture industry

Inconsistency $=0.01$

with 0 missing judgments.

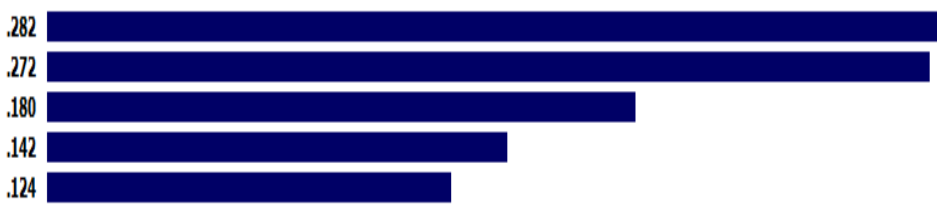

Figure 9:- Computed alternative priorities with respect to Readiness of businessmen criterion.

Market acceptance:-

\begin{tabular}{|l|rrrr|r|}
\hline & Incentives to furniture & Assistance, socialization \& education & Group Certification & Promotion of SVLK and campaign against illegal Voluntary in furniture industry \\
\hline Incentives to furniture industry & 1.12073 & 1.51861 & 1.61999 & 1.61999 \\
\hline Assistance, socialization \& education & & 1.8435 & 3.26817 & 3.94945 \\
\hline Group Certification & & & 1.08447 & 2.20772 \\
\hline Promotion of SVLK and campaign ac & & & 1.25097 \\
\hline Voluntary in furniture industry Incon: 0.02 & & & & \\
\hline
\end{tabular}

Figure 10:- Pair wise matrix to Market acceptance criterion.

Priorities with respect to:

Combined

Goak: Implementation Strategy of SVLK in the Furniture Industry in Indonesia

>Market acceptance

Incentives to furniture industry

Assistance, socialization \& education and training

Group Certification

Promotion of 5VLK and campaign againstillegal timber trading

Voluntary in furiture industry

Inconsistency $=0.02$

with 0 missing judgments.

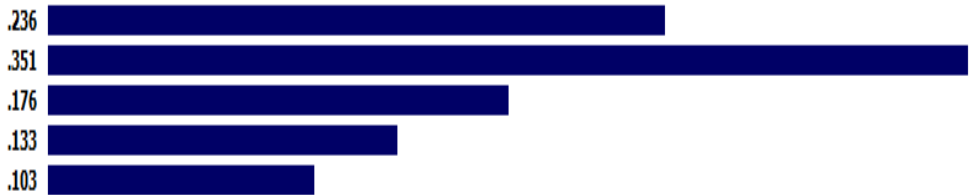

Figure 11:- Computed alternative priorities with respect to Market acceptance criterion.

Calculating priorities for different criteria:-

Priorities for each criterion/factor are summarized as follows:

Table 3:- Priorities for the criteria.

\begin{tabular}{|c|c|}
\hline Criteria for the factor evaluation & Priorities \\
\hline Government policy & .404 \\
\hline Readiness of implementing bodies & .238 \\
\hline Readiness of businessmen & .199 \\
\hline Market acceptance & .159 \\
\hline
\end{tabular}

Table 4:- Priorities of the alternatives with respect to each criterion.

\begin{tabular}{|l|c|c|c|c|}
\hline \multicolumn{1}{|c|}{ Criteria/factor } & $\begin{array}{c}\text { Government } \\
\text { policy }\end{array}$ & $\begin{array}{c}\text { Readiness of } \\
\text { implementing } \\
\text { bodies }\end{array}$ & $\begin{array}{c}\text { Readiness of } \\
\text { businessmen }\end{array}$ & $\begin{array}{c}\text { Market } \\
\text { acceptance }\end{array}$ \\
\hline Incentives to furniture industry & .341 & .270 & .282 & .236 \\
\hline $\begin{array}{l}\text { Assistance, socialization, education and } \\
\text { training }\end{array}$ & .261 & .333 & .272 & .351 \\
\hline Group certification & .172 & .169 & .180 & .176 \\
\hline
\end{tabular}




\begin{tabular}{|l|c|c|c|c|}
\hline $\begin{array}{l}\text { Promotion of SVLK and campaign } \\
\text { against illegal timber trading }\end{array}$ & .138 & .140 & .142 & .133 \\
\hline Voluntary in furniture industry & .088 & .088 & .124 & .103 \\
\hline
\end{tabular}

Calculation of overall priority of all Alternatives:-

The results from Expert Choice Software were used to calculate priority for each alternative as shown below:

Overall priority for incentives to furniture industry alternative

$=(0.404 \times 0.341)+(0.238 \times 0.270)+(0.199 \times 0.282)+(0.159 \times 0.236)$

$=(0.137+0.064+0.056+0.037)$

$=0.294$

Overall priority for assistance, socialization, education and training alternative

$=(0.404 \times 0.261)+(0.238 \times 0.333)+(0.199 \times 0.272)+(0.159 \times 0.351)$

$=(0.105+0.079+0.054+0.055)$

$=0.293$

Overall priority for group certification alternative

$=(0.404 \times 0.172)+(0.238 \times 0.169)+(0.199 \times 0.180)+(0.159 \times 0.176)$

$=(0.069+0.040+0.035+0.027)$

$=0.171$

Overall priority for Promotion of SVLK and campaign against illegal timber trading alternative

$=(0.404 \times 0.138)+(0.238 \times 0.140)+(0.199 \times 0.142)+(0.159 \times 0.133)$

$=(0.055+0.033+0.028+0.021)$

$=0.137$

Overall priority for voluntary in furniture industry alternative

$=(0.404 \times 0.088)+(0.238 \times 0.088)+(0.199 \times 0.124)+(0.159 \times 0.103)$

$=(0.035+0.020+0.024+0.016)$

$=0.095$

The findings show that Incentives to furniture industry received the highest priority at 0.294 thus being the best alternative in the implementation of SVLK in the furniture in Indonesia followed by the assistance, socialization, education and training priority at 0.293 , group certification at 0.171 , promotion of SVLK and campaign against illegal timber trading priority at 0.137 , and voluntary in furniture industry priority at 0.095 .

The strategy of incentives to furniture industry indicates that the furniture industry in Indonesia is in need of full government support to encourage the entire furniture industry to get SVLK certificate. The incentive is recognized as a form of stimulant to industry and the implementation of these incentives can take the form of cost subsidy, technical assistance on easiness in licensing, export process, and others.

\section{Conclusion:-}

Factors that influence the implementation of SVLK in the furniture industry in Indonesia consists of internal factors such as strength, namely (1) Indonesia government policies that have ratified the Voluntary Partnership Agreement (VPA) with the European Union, (2) The involvement of stakeholders in making policy of SVLK, and (3) The centers of the furniture industry in Indonesia with a market share of exports. Internal factors such as weakness, namely (1) Unpreparedness of companies mainly classified as Small and Medium Enterprises (SMEs), (2) Raising of new fees, (3) The difference in perception towards SVLK between the government and the business world, (4) Number of LVLK with furniture companies are not comparable and the limited number of Timber Legality Verification auditors, and (5) The local market for SVLK certified products is not established yet.

External factors such as opportunities, namely (1) The policy of export destinations which requires the legality of timber, (2) Pressure from international environmental organizations to use legal wood products (3) Perceptions of foreign buyers give a good image of the company that cares about our environment, and (4) The furniture market network of ecolabel certified wood raw materials. External factors like threats which are: (1) No proven international market acceptance of SVLK, (2) Existence of illegal timber trading and (3) Cheap furniture products from other countries. 
The best alternative implementation strategy of SVLK in the furniture industry was found to be incentives to furniture industry indicating that the furniture industry in Indonesia is in need of full government support to encourage the entire furniture industry to get SVLK certificate. The incentive is recognized as a form of stimulant to industry and the implementation of these incentives can take the form of cost subsidy, technical assistance on easiness in licensing, export process, and others. The implementation of incentives can take the form of cost subsidy, technical assistance on easiness in licensing, export process, and others. This study is therefore helpful to governments, accreditation bodies, and certification bodies in promoting forest certification in Indonesia in order to ensure that a sustainable forest management is achieved.

\section{Acknowledgements:-}

The authors gratefully acknowledge funding by Science and Technology Commission of Shanghai Municipality within the project "Chongming Island natural resource accounting and management mechanism" for supporting the methodology development. For the invaluable exchanges of information and ideas, we are grateful to the respondents from MoEF, MoT, KAN, PT. BRIK Quality Services (BRIK), Independent Forestry Monitoring Network (JPIK), Indonesian Center for Environmental Law (ICEL) and Indonesia Furniture and Handicraft Industry Association (ASMINDO) for providing us the information we required. We also acknowledge Caleb Obonyo for proofreading the manuscript.

\section{Reference:-}

1. BPS Badan Pusat Statistik [Online] // Badan Pusat Statistik. - 2017. - January 12, 2017. https://www.bps.go.id/all_newtemplate.php.

2. BPS Badan Pusat Statistik [Online] // Badan Pusat Statistik. - 2016. - January 12, 2017. https://www.bps.go.id/all_newtemplate.php.

3. Cashore Benjamin and Stone Michael W. Does California need Delaware? Explaining Indonesian, Chinese, and United States support for legality compliance of internationally traded products [Journal] // Regulation \& Governance. - 2014. - pp. 49-73.

4. Cashore Benjamin and Stone Michael W. Review: Can legality verification rescue global forest governance? Analyzing the potential of public and private policy intersection to ameliorate forest challenges in Southeast Asia [Journal] // Forest Policy and Economics journal. - 2012. - pp. 13-22.

5. Donegan H A, Dodd F J and McMaster T B. M A New Approach to AHP Decision-Making [Journal]. Ireland : Wiley for the Royal Statistical Society, 1991. - 3 : Vol. 41.

6. David Fred R. Strategic management: concepts and cases [Book]. - Saddle River, New Jersey: Pearson Education, Inc, 2011. - Thirteenth.

7. FAO Global Forest Resources Assessment 2015 Desk reference [Book]. - Rome : Food and Agriculture Organization of the United Nations, 2015.

8. Feja Lesniewska and McDermott Constance L. FLEGT VPAs: Laying a pathway to sustainability via legality lessons from Ghana and Indonesia [Journal] // Forest Policy and Economics. - 2014. - pp. 16 - 23.

9. Gaspersz Vincent Perencanaan Strategik untuk Peningkatan Kinerja Sektor Publik: Suatu Petunjuk Praktek [Book]. - Jakarta, Indonesia : Gramedia Pustaka Utama, 2003.

10. Heeswijk Laura van and Turnhout Esther The discursive structure of FLEGT (Forest Law Enforcement, Governance and Trade): The negotiation and interpretation of legality in the EU and Indonesia [Journal] // Forest Policy and Economics. - [s.1.] : Forest Policy and Economics, 2013. - Vol. 6. - pp. 6-13.

11. Institute European Forest VPA countries [Online] // EU FLEGT Facility. - 2014. - January 23, 2017. www.euflegt.efi.int/vpa-countries.

12. Ivers Laura and Mead Leila Summary Report of The Forest Law Enforcement And Governance East Asia Ministerial Conference [Online] // International Institute for Sustainable Development (IISD). - September 11, 2001. - January 23, 2017. - http://www.iisd.ca/crs/sdfle/sdvol60num1.html.

13. Kurttila Mikko [et al.] Utilizing the analytic hierarchy process AHP in SWOT- analysis - a hybrid method and its application to a forest-certification case [Journal] // Forest Policy and Economics. - 2000. - pp. 41-52.

14. LEI Menjamin Kayu Legal Dari Hutan Kita: Sistem Verifikasi Legalitas Kayu (Versi Stakeholder) [Online] // Lembaga Ekolabel Indonesia. - 2017. - January 26, 2017. - http://www.lei.or.id/resource/91/sistem-verifikasilegalitas-kayu-versi-stakeholder.

15. Luttrell Cecilia [et al.] Lessons for REDD+ from measures to control illegal logging in Indonesia [Book]. Jakarta and Bogor, Indonesia : United Nations Office on Drugs and Crime and Center for International Forestry Research, 2011. 
16. Marimin and Maghfiroh Nurul Aplikasi Teknik Pengambilan Keputusan dalam Manajemen Rantai Pasok [Book]. - Bogor, Indonesia : IPB Press, 2010.

17. Marimin Teknik dan Aplikasi Pengambilan Keputusan Kriteria Majemuk [Book]. - Jakarta, Indoanesia : Grasindo, Gramedia Widiasarana Indonesia, 2004.

18. Maryudi Ahmad Choosing timber legality verification as a policy instrument to combat illegal logging [Journal] // Forest Policy and Economics. - 2016. - pp. 99-104.

19. Melati, Purnomo Herry and Shantiko Bayuni Making research work for small-scale furniture makers: Action research in the Jepara furniture industry, Indonesia [Book]. - Bogor, Indonesia : Center for International Forestry Research, 2013.

20. Ministry of Environment and Forestry Sistem Informasi Legalitas Kayu (SILK). Timber Legality Information System (TLIS) [Online] // Ministry of Environment and Forestry. - February 2017. - February 09, 2017. - http://silk.dephut.go.id/index.php/info/lvlk.

21. MoEF Ministry Environment and Forest [Online] // Ministry Environment and Forest. - 2017. - January 11, 2017. - http://www.menlh.go.id/penebangan-hutan-dan-deforestasi-fakta-dan-angka/.

22. MoEF Ministry of Environment and Forestry Statistics 2015 [Report]. - Jakarta : Ministry of Environment and Forest, 2016.

23. MoEF Sistem Informasi Legalitas Kayu (SILK) [Online] // Ministry of Envoronment and Forestry. - 2017. January 12, 2017. - http://silk.dephut.go.id/index.php/info/svlk.

24. MoEF Timber Legality Information System (TLIS) [Online]. - January 15, 2017. - January 15, 2017. http://silk.dephut.go.id/index.php/info/vsvlk/1.

25. MoEF Timber Legality Information System (TLIS) [Online] // Ministry of Environment and Forestry. - January 23, 2017. - January 23, 2017. - http://silk.dephut.go.id/index.php/info/vsvlk/1.

26. MoEF Timber Legality Information System (TLIS) [Online] // Ministry of Environment and Forestry. - January 23, 2017. - January 23, 2017. - http://silk.dephut.go.id/index.php/info/vsvlk/1.

27. Multi Stakeholder Forestry Programme [Online] // Multi Stakeholder Forestry Programme (MFP). - 2017. January 23, 2017. - http://www.mfp.or.id/index.php/id/.

28. Nellemann Christian and Programme INTERPOL Environment Green Carbon, Black Trade: Illegal Logging, Tax Fraud and Laundering in the Worlds [Book]. - [s.1.] : A Rapid Response Assessment. United Nations Environment Programme, GRID-Arendal, 2012.

29. Nurrochmat Dodik Ridho [et al.] Contesting national and international forest regimes: Case of timber legality certification for community forests in Central Java, Indonesia [Journal] // Forest Policy and Economics journal. - 2016. - pp. 54-64.

30. Pohnan Erica and Stone Michael Can Legality Verification Combat Illegal Logging in Indonesia? Strategic Insights [Journal] // IUFRO Task Force on Forest Governance. - 2013. - pp. 1-8.

31. Setianingsih Betty Kebijakan Pemberantasan Illegal Logging untuk Perlindungan Sumberdaya Hutan di Indonesia [Book]. - Bogor, Indonesia : Bogor Agricultural University (IPB), 2009.

32. Setiono Bambang and Yunus Husein Fighting forest crime and promoting prudent banking for sustainable forest management. The anti money laundering approach [Book]. - Bogor, Indonesia : Center for International Forestry Research (CIFOR), 2005.

33. World Customs Organization What is the Harmonized System? [Online]. - 2017. - 03 01, 2017. http://www.wcoomd.org/en/topics/nomenclature/overview/what-is-the-harmonized-system.aspx. 